\title{
Ethiopian Cattle Genetic Resource and Unique Characteristics under a Rapidly Changing Production Environment-A Review
}

\author{
Berhane Hagos \\ Adigrat University, College of Agriculture, Department of Animal Production and Technology, Adgrat, Tigray, Ethiopia \\ Address: Adigrat University, P.O.Box 50
}

\begin{abstract}
Ethiopia is endowed with diverse cattle genetic resources adapted to various local environmental conditions and acquired unique features. Describing of the unique characteristics, the necessity and urgency to understand and utilize these genetic resources is respond to the needs of the people of the nation and to the benefit of Ethiopian cattle producers. Thus, this review is aimed to summaries the cattle genetic resources, their unique features, main causes of threat for survival and to recommend on their improvement and conservation strategies. Today, we find a variety of genetically diverse population from Bos taurus to Bos indicus species with unique adaptation characteristics in Ethiopia. These cattle breeds are found all across the country from the rift valley highlands as well as below sea level in the Afar depression. However, despite the potentials of these diversified genetic resources, their unique genetic features, these cattle breeds are at risk to disappear rapidly following uncontrolled cross breeding, breed replacements with exotic breeds and other challenges. Breed improvement programs of Ethiopian indigenous cattle remain too few while the demand of livestock products is continually increasing. This situation therefore demands the need to devise strategies to conserve and improve the cattle breeds based on the challenges that threatens them. Use of genomic study is also imperative to facilitate the genetic restoration process. Besides, uses of new information technologies which can enhance the conservation and improvement program are very crucial. Various ongoing development interventions like Artificial Insemination and introduction of genotypes into new environments that are exacerbating threat of the breeds should be revised and a sound approaches for cattle Conservation and improvement programs should be redesigned. Strict regulations and bylaws should also be in place for illegal movement of breeding cattle to the neighboring countries.
\end{abstract}

Keywords: Unique, Genetic Resources, Indigenous Cattle

\section{Introduction}

Staring from domestication of animals, livestock populations have continually been influenced through selective breeding in response to the needs of the owners as well as through natural selection to adapt to the local production environment. Animal breeding was initially practiced to obtain usable products or services and for socio-cultural reasons. Although from the very oldest breeding schemes might have existed, knowledge-based selective breeding was first practiced by the Romans [1]. However, the commercial livestock sector is facing several new challenges. Demand for livestock products is continuously increasing, but longterm sustainability of the intensive livestock sector is questionable [2]. Climate change is putting new pressures on livestock production, while livestock themselves are contributing through greenhouse emissions to the climate change [3], [4]. Moreover, despite indigenous livestock are adapted to the local environments, they are poor milk and meat producers compared to the commercial breeds raised in the extensive system [5]. Based on the above concerns and the need to viaduct the huge productivity gaps in developing countries, threaten by rapid changes in the production systems, more than ever indigenous livestock genetic resources, which constitute the largest proportion of livestock in those countries, are increasingly being eroded through poorly planned crossbreeding and breed replacements. In process, we might be losing their unique attributes, especially those responsible for adaptations to the past, current, and even future Ethiopian environmental challenges, such as feed shortage tolerance, parasitic infectious diseases, heat and drought tolerance etc. Hence, this paper summarizes the characteristics and adaptation of indigenous Ethiopian cattle emphasizing the importance and need to untie and characterize these cattle at molecular level for better understanding of the situation of these breeds for the collective efforts towards conserving and improving the breeds.

\section{The Origin of Ethiopian Cattle Breeds}

East Africa and Ethiopia in particular own the highest concentration of domesticated and diversified cattle (Bos indicus and Bos taurus) in the continent [6]. [7] Also concluded that Ethiopia is the cradle of the largest number of African zebu population. This might be because of the fact that Ethiopia is believed to have been a gateway for cattle immigrations into Africa [8]. It is indicated that cattle may have penetrated to Ethiopia in the middle of second millennium B.C [9]. According to [6], Ethiopia, is considered to be a supposed migratory corridor for both Near-East Bos taurine and Arabian and Indian Bos indicus cattle into East Africa. Therefore, in general, the country is considered as the home of most important cattle breeds for eastern and southern Africa [8],[10] and enriched with 28 recognized indigenous cattle breeds and 7 exotic breeds [11]. The diverse agro-ecology, cultural and ethnic diversity, a long-lasting agricultural practice and farming systems in the country have contributed to be a centre of secondary diversification for livestock in the continent [13],[12]. Present-day Ethiopian cattle population can be classified as large and small East African Zebu, Sanga and Zenga type [14], [15]. 


\section{International Journal of Science and Research (IJSR) \\ ISSN (Online): 2319-7064}

Index Copernicus Value (2016): 79.57 | Impact Factor (2015): 6.391

However, often the genetic distinctiveness between these Cattle breeds remain largely unknown and it may be more appropriate to talk about Ethiopian cattle populations or ecotypes. The intervention trials of the animal diversity in Ethiopia have been poorly addressed in contrary to the efforts made on recognition of the importance of conserving plant biodiversity [16]. The situation is very serious in developing country like Ethiopia where rapid changes in production systems are leading to replacement of the breeds or at best cross breeding [17]. In this regard, [18] stated that knowledge regarding the unique characteristics and the threats facing particular breeds and production systems is yet inconsistent and often unavailable to relevant stakeholders. The absence of information on the level of genetic introgression of the indigenous Boran and Sheko cattle [16] can be a very good example. The lack of knowledge about threats often goes hand in hand with a more general lack of knowledge about the characteristics, use, management and distribution of livestock breeds [18]. For instance, in the absence of conservation measures to be implemented, half of the current cattle diversity in Africa will be lost in the next 20-50 years [19). This situation in our country is becoming serious. Though most parts of the country have been assessed in-terms of identifying the livestock genetic resources, some of the livestock breeds identified are found at risk with unwise utilization of each breed consecrated.

Thus, in aware of these facts there is a need to sensitize the scientific community, funding organizations, research institutes, government officials and others to come together and internalize the problem first, to design conservation and utilization strategies, and to show their commitment for the implementation of sustainable breeding/conservation programs so as to alleviate the challenge our indigenous cattle genetic resources are facing. Ethiopian indigenous cattle are found in all parts of the country, while commercial taurine breeds and their crossbreed are found almost in urban areas for commercial purpose, although their populations are relatively low compared to the indigenous breeds.

\section{Types of Indigenous Cattle and Their Geographic Distribution}

Main groups of Ethiopian Indigenous cattle can be broadly classified into four categories: Large East African Zebu, Sanga, Small East African Zebu, Zenga (zenga, defined as SangaxZebu backcross). In addition to these four categories, other Ethiopian cattle breeds have been recently derived through recent crossbreeding with exotic [20]. Large east African zebu includes; North Sudan zebu (Begait cattle), Boran (Ethiopian Boran cattle) and Abyssinian short honed zebu (Arisi cattle). They mostly inhabit North West, south and central highland of Ethiopia respectively. Both these have unique evolutionary adaptation to harsh climate [21] and various endemic diseases [21, [22].

Small east African zebu is classified as Abyssinian shorthorn zebu and are found in different agro-ecology and named in to different breed names these includes (Bale and Jem-Jem cattle) in Sidamo and Bale mountain, (Harar cattle) in Hararghe highland, (Ogaden cattle) in Eastern Ethiopia,
(Sheko/Smad cattle) in the highlands of southern Gondar, (Adwa cattle) in Tigriay region northern Ethiopia, (JigJIga cattle) in Somali region of south-eastern Ethiopia, (Goffa cattle) in the wet and warm south-western highlands of Ethiopia, (Guraghe cattle) in the tsetse-infested valleys of the Ghibe tributaries,(Hammer cattle) in the South Omo zone of southern Ethiopia, (Ambo cattle) in the western Shoa of central Ethiopia [8],[2]. Zebu cattle (Bos indicus), are the majority of cattle types in Ethiopia. They have a fatty thoracic hump on their shoulders and a large dewlap. The zebu is usually susceptible to trypanosomosis [23] however; tolerance to the disease has been documented in the Boran, Large East African zebu breed [24]. They are adapted to dry environmental conditions and high temperatures and are known to be more resistant to tick infestation compared to Bos taurus cattle [22]. Ethiopian zebu cattle inhabit in all parts of the country. Their small body size and high production levels in tsetse-free areas have made them more appealing to the local farmers, and therefore partly explain their abundance and wide distributions.

The Sanga is an intermediate type of cattle, which is a cross between Bos taurus and Bos indicus. They are humped but the hump is cervico-thoracic rather than thoracic. The term 'Sanga' is an Ethiopian word meaning 'bull' and it relates to the origin and centre of dispersal of this group of cattle breeds. This breed group includes (Anuak cattle) which is found in Gambela south-western Ethiopia, (Raya Azebo cattle) in Tigray and Wello in north-eastern highlands of Ethiopia. These are slightly bigger animal, probably a result of selection for draught power for the settled agricultural practice [25]. The Sanga show a mixture of features from the zebu (humps and dewlap) and Humpless cattle (long horns and no humps). However, recent molecular genetic evidence [8] suggests that genetic introgression of the Bos indicus (zebu) spread from the Horn of Africa to the west of the continent and the zebu genes might have dispersed rapidly into the indigenous Africa populations. The present distribution of the Sanga cattle extends from Eritrea, through Ethiopia, southern Sudan of eastern Africa. They inhabit south-west and north-eastern Ethiopia and are known to be well adapted to seasonally harsh conditions [26].

After persist crossbreeding between Sanga cattle and newly introduced zebu led to a new cattle type called "Zenga" [6]. The Ethiopian Zenga breed group includes (Fogera cattle) found in western Amhara region and (Arado cattle) found in the highlands of Eritrea (Akale-Guzay and Seraye in the north), and northern Ethiopia (northern Shire, Adwa and parts of Agame [25]. Therefore, in general, the country is considered as the home of most important cattle breeds for eastern and southern Africa [8],[10] and enriched with 28 recognized indigenous cattle breeds [11]. The diverse agroecology, cultural and ethnic diversity, a long-lasting agricultural practice and farming systems in the country have contributed to be a centre of secondary diversification for livestock in the continent [11],[12]. Despite the potentials of diversified genetic resource, the huge loss of livestock genetic diversity will seriously undermine the efforts towards achieving food security and poverty reduction [28] viz avis the long-term effect on global biodiversity. This on-going loss of the livestock genetic heritage is tantamount to losing a road map for survival - the

\section{Volume 6 Issue 12, December 2017}




\section{International Journal of Science and Research (IJSR) \\ ISSN (Online): 2319-7064}

Index Copernicus Value (2016): 79.57 | Impact Factor (2015): 6.391

key to food security, environmental stability and improving the human condition [30].

According to various scholars report, the situation in Ethiopia seems very critical and remarks to be keen in terms of internalizing the challenges, revising development intervention approaches which are threatening potential breeds and to redesign them, and bringing the fragmented hands together and act accordingly. For instance, in the last 17 years, different literatures indicate that there is very high population reduction of Sheko breed. According to [6] who had identified Sheko cattle (the humpless shorthorn of East African cattle group) breed as endangered breed in Ethiopia, the population was estimated about 31,000 and later declined to 4040 which constitute only $2 \%$ of the total cattle population in the known breeding tract of Sheko [31], [33], further declined to 2400 [30], [34] by the year 1967and 2011 [32].

Moreover, some breeds that are critically endangered animals, such as the Begait and Boran (East African Zebu), Fogera (Zenga), Irob (Small East African Zebu), Raya Azebo (Snga) [6]. To compensate for the relatively lower production potential of indigenous cattle, crossbreeding of these cattle with exotic breeds, is commonly practiced, with minimal within breed selection program for the indigenous breeds. The end result is a continuous erosion and loss of cattle diversity, including for adaptive traits, before these genetic resources are fully characterized. There is therefore an urgent genomic studies need to comprehensively characterize the Ethiopian cattle populations, in order to objectively inform their utilization and conservation before they disappear [36].

\section{Characteristics of Ethiopian Indigenous Cattle Breeds}

Ethiopian indigenous cattle breeds have unique morphological features which distinguishes them from other cattle. These include horn shape and size (e.g. Afar and Raya breed) and body size (large and small east African Zebu) [37], [38]. In addition to physical features, non-visible traits such as disease resistance, climatic stress resistance and productivity traits also differ among breeds. These characteristics are largely the result of natural and human selection. Some breeds are already known for their unique adaptive attributes (e.g. Sheko) or good economic performances (e.g. Ethiopian Boran). One of the well-known outstanding features of Ethiopian cattle is trypanosomosis resistance. Trypanosomosis is a tsetse-transmitted disease in vertebrates. In cattle the main pathogenic trypanosomes are Trypanosome Congolese and T. vivax. Temperate cattle breeds are highly susceptible to trypanosomes infection.

Table 1: Ethiopian indigenous cattle breeds with their characteristics

\begin{tabular}{|c|c|c|}
\hline Group Name & Breed Name & Characteristics \\
\hline Large East & Begait & Active disposition \\
\cline { 2 - 3 } African Zebu & $\begin{array}{c}\text { Ethiopian } \\
\text { Boran }\end{array}$ & $\begin{array}{c}\text { Walking ability, highly adapted to } \\
\text { harsh conditions, herd instinct, } \\
\text { mothering ability, longevity, large } \\
\text { sex dimorphism }\end{array}$ \\
\hline Small East & Arisi cattle & Poor milkers, extremely active and \\
\hline
\end{tabular}

\begin{tabular}{|c|c|c|}
\hline \multirow{7}{*}{ African Zebu } & & often very aggressive \\
\hline & Jem-jem & $\begin{array}{l}\text { Well adapted to wet and cold } \\
\text { climate }\end{array}$ \\
\hline & Ogaden & Good dairy and beef characteristics \\
\hline & Adwa cattle & $\begin{array}{l}\text { high temperatures and are known to } \\
\text { be more resistant to tick infestation }\end{array}$ \\
\hline & Harar cattle & $\begin{array}{l}\text { are known to be more resistant to } \\
\text { tick infestation }\end{array}$ \\
\hline & Jijiga cattle & $\begin{array}{l}\text { adapted to dry environmental } \\
\text { conditions }\end{array}$ \\
\hline & $\begin{array}{l}\text { Goffa and } \\
\text { Guraghe }\end{array}$ & $\begin{array}{l}\text { high temperatures and are known to } \\
\text { be more resistant to tick infestation }\end{array}$ \\
\hline & Ambo cattle & $\begin{array}{l}\text { high temperatures and are known to } \\
\text { be more resistant to tick infestation }\end{array}$ \\
\hline \multirow{2}{*}{$\begin{array}{c}\text { East African } \\
\text { Sanga } \\
\end{array}$} & Raya Azebo & Good draught power \\
\hline & Anugak & Tolerance to Trypanosomosis \\
\hline \multirow[t]{3}{*}{ Zenga } & Fogera cattle & $\begin{array}{l}\text { be able to survive on very poor } \\
\text { pasture, scarce water and have good } \\
\text { walking abilities }\end{array}$ \\
\hline & Afar cattle & $\begin{array}{c}\text { be able to survive on very poor } \\
\text { pasture, scarce water and have good } \\
\text { walking abilities }\end{array}$ \\
\hline & Arado cattle & $\begin{array}{c}\text { be able to survive on very poor } \\
\text { pasture, scarce water and have good } \\
\text { walking abilities }\end{array}$ \\
\hline $\begin{array}{l}\text { Humpless } \\
\text { shorthorn }\end{array}$ & Sheko cattle & Tolerance to Trypanosomosis \\
\hline \multicolumn{3}{|c|}{ Source, [39] } \\
\hline
\end{tabular}

The Ethiopian Bos taurus type are tolerant while Ethiopian Bos indicus are susceptible although not as susceptible as the non-Ethiopian Bos taurus and Bos indicus exotic breeds. For instance, the Sheko cattle (East African hump less shorthorns) show also resistance to trypanosomosis [41]. Unfortunately today, this cattle breed is rapidly disappearing as result of increasingly being crossed with Trypanosusceptible zebu cattle. Although zebu cattle are usually susceptible to trypanosomosis, some zebu breeds that inhabit tsetse-infested regions, such as the southwestern Ethiopia specifically at the humid Sheko and Bench districts. The Ethiopian Boran, and the Goffa cattle have been reported to have relatively reasonable levels of tolerance to trypanosomosis, as a result of local evolutionary adaptation [25], [47].

In Ethiopia, cattle breeds have adapted to hot and dry weather, but others have adapted to even cold and wet conditions, such as Jem-Jem cattle (Small East African Zebu) in Ethiopia [25] Both Boran, Afar and Begait are drought tolerant and withstand water thirst. Boran cattle can stay two to three days without water thirst [16]. The genes that Boran cattle carry are mainly the result of a long-term natural selection under harsh environmental conditions. They have developed adaptive traits of crucial importance for their survival [61]. [27] indicated that Begait cattle breed is well adaptive to arid and semi-arid conditions where as Fogera cattle adapt to survive in flooded and swampy areas for several months. In addition, Guraghe cattle (Abyssinian shorthorn Zebu), have very high tolerance to heavy tick challenges [37].

Distinct evolutionary history between Bos taurus and B. indicus have resulted in different degree of thermo-tolerance at the cellular and physiological levels. Bos indicus breeds can effectively regulate their body temperature against 


\section{International Journal of Science and Research (IJSR) \\ ISSN (Online): 2319-7064}

Index Copernicus Value (2016): 79.57 | Impact Factor (2015): 6.391

thermal stress and are better adapted to hot weather than Bos taurus breeds. In addition, several breeds of zebu and Zenga are able to withstand very harsh environmental conditions, and those characteristics have arisen through evolutionary adaptation. For examples, Begait cattle (Large East African Zebu) found in North-Western Ethiopia are well adapted to very dry climates and they can survive if they are able to drink only once every two days [28]. Afar cattle (Sanga) and Raya Azebo cattle (Small East African Zebu) in Afar region eastern Ethiopia and in Tiray region north-Ethiopia respectively, are adapted to browsing during the long dry seasons [25]. Jigjiga, Ogaden and Adwa cattle (small east African zebu) and Afar cattle (Sanga) which are found in Ethiopian Somali region, Tigray region and Afar region, respectively are thought to be able to survive on very poor pasture, scarce water and have good walking abilities. Ethiopian cattle continue to play a major role in the socioeconomic development and nutritional security of the people of the country. It is likely that some of the earliest Ethiopian societies depended only on livestock given their nomadic lifestyle [38].

Pastoralism as a system remains an important activity in the country today, and exemplified by the Afar, Somalia's and the Borena communities. Across the country cattle remain major socio-cultural assets and they play important sociocultural roles in many African societies (e.g. marriage, initiation). Besides these major socio-cultural roles, Ethiopian cattle represent a major source of animal protein (dairy product and beef), provide draft power, thus support crop farming, and fertilizer through manure, which is also used as fuel by some communities. Some indigenous Ethiopian cattle breeds are known to have both good dairy and beef characteristics [25], [42]. For example, the Begait or Barka cattle (Large East African zebu), which inhabit northwestern Ethiopia and southern Eritrea, show good performance both as a dairy and beef breed [43]. Other wellknown beef-dairy cattle are Ogaden cattle (Small East African Zebu) [25] and Fogera cattle (Zenga) [44]. For commercial cattle breeds artificial selection and management interventions have resulted in markedly productivity improvements and by extension, economic performance but at the cost of reduced genetic diversity and in some case fertility [17],[45]. In contrast, most Ethiopian cattle breeds have not been selected consistently for productivity gains. Rather the main selection focus has been on survival, in often unpredictable, harsh and changing environmental conditions. According to the report from [11], [39], Ethiopia possess cattle breeds having higher genetic diversity than cattle breeds in other countries in Africa.

\section{Potential Causes of Threats and Best Intervention}

African cattle breeds are facing aggravate threat of their survival. These includes: unfair competition from vigorously promoted commercial European breeds, even where such genotypes are inappropriate, unplanned crossbreeding with commercial European breeds, globalization and the supermarket revolution where standards of livestock products are made to mirror the developed world ${ }^{\text {ee }} \mathrm{s}$ tastes and requirements, absent or poor breeding program design and implementation plans, lack of infrastructure (e.g. recording systems, breeders organizations etc.) and policy frameworks to support sustainable breed improvement programs among others [46]. Similarly Ethiopian indigenous cattle breeds are threatening of their survival and some of the major contributing factors can be mentioned.

\subsection{High rate gene flow and Genetic dilution among indigenous breeds}

The presence of high gene flow and admixture between indigenous cattle breeds is one of the major contributing factors in threatening unique cattle breeds [27], [40]. In Borana area, pastoralists usually move to look for feed and water resources which leads the breed to be admixed with the surrounding small sized zebu in the watering and feeding points [47], [16]. Similarly, there is indiscriminate crossbreeding and high affinity of replacing Sheko cattle by other thoracic-humped zebu cattle which have good temperament [6],[31],[32], [34]. With this respect, the molecular genetic evidence also showed that about $90 \%$ of the sampled Sheko bulls have had their specific taurine allele replaced by indicine allele confirming an alarming introgression of Zebu genes [7]. In the pastoral area, like Borana plateau, the conflict between clans on control over resources has also contributed to genetic admixture due to raiding. In general, various molecular studies [48], [49], [27], [35], [17], [20] conducted on indigenous cattle genetic resources in Ethiopia indicate that the genetic diversity among breeds is very minimal. This is just because of the fact that there is high pressure of breed admixture and uncontrolled breeding program.

\subsection{Decreasing of grazing lands}

Pasture and grazing lands are reducing due to increment of farm land for crop cultivation, biological and/or behavioral nature of the breeds, natural disaster and other development interventions. For instance, apart from the aggressive nature of the breed which provides difficult to manage the animals in tethered feeding system Sheko breed is known with its high feed intake that contrasts to the high farm land expansion in the home track and consequently causes to shrinkage of grazing land [6]; [33], [34]. On the other hand, pastoralists identified scarcity of pasture in Borana range land due to the increasing recurrence of droughts as the main cause shrinkage of the grazing land [50]. Due to this, cattle are losing their predominant position to small ruminants and camels [51], [50]. [52] also stated that the change in the rangeland condition has infavoured cattle rearing compared to camel and goat production. The shift from livestock dominant mixed crop livestock production system to crop dominant mixed crop livestock system has also affected the indigenous Fogera and Begait cattle breeds. In this regard, the expansion of dominantly rice, Sesame and other crop farming at the expense of productive communal lands is interfering with the production and productivity potential of the breed [53]. 


\section{International Journal of Science and Research (IJSR) \\ ISSN (Online): 2319-7064}

Index Copernicus Value (2016): 79.57 | Impact Factor (2015): 6.391

5.3. Lack of institutionalized breed improvement programs

Various studies indicated that in most of the indigenous cattle breeds in Ethiopia, there is no any active research and development work targeted towards conservation, example, Sheko cattle [31]. Rather, mostly practiced breed improvement interventions are contributing for the loss of indigenous genetic resources. When one can see the interest of conserving the local livestock types has decreased over the last 25 years in response to the expansion of highly productive livestock breeds at the expense of local populations (Hall, 2004). For instance, there is provision of AI service (exotic blood) in the home land of Sheko breed and introduction of Boran breed for farmers with a subsidized cost in some selected districts of bench Maji zone [31]. Such treat of introduction of Boran cattle breed was practiced, still going on, in Metema area and other places. The restocking programs by Non Governmental Organizations (NGOs) was identified and considered potential influential factor in changing the genetic constitution of the native breed populations. In line with this [6] reported that $50 \%$ of farmers ${ }^{\text {ee }}$ herds are composed of admixture in Borana area. The lack of institutionalized schemes for genetic improvement of the breeds have encouraged the practice of exchanging of superior bulls among closely related herdsmen apart from the massive admixture of herds of various origins [28], [29] which have unique and potential attributes. This practice is significantly observed among north Ethiopian indigenous cattle breeds including Fogera and Begait cattle.

\subsection{Discriminate selection of gene pool}

Different literatures revealed that there is intentional cross breeding between indigenous cattle breeds in search of large size animals [47], [16]. Due to this reason, many development agents pick better performing animals from their home tract and introduce to other environments with complete negligence on the fate of the breed and its effect on the genetic dilution with the native indigenous breeds. For instance, Fogera cattle breed is preferred for its relatively larger body size for domestic market and illegal foreign trade to Sudan border. Apart from that, it is quite clear that Ethiopia is home and main gate of many of African cattle breeds, example, the Boran breed which is now widely distributed beyond Africa. Kenya is the major beneficiary in providing the improved Boran gene pool to the market. Many of the countries which introduced the Boran have developed their own Boran breed [53]. The performance difference of Boran at its original home land and where it is improved is quite large. In general, these all points indicated above provide evidences how indigenous cattle populations are losing their initial genetic architecture and landscape.

\section{Appropriate Options to be Considered During Interventions}

\subsection{Insuring sufficient infrastructure}

African countries are described with shortage of the technical, physical, institutional and financial resource capacity needed to enable sustainable utilization and genetic improvement of their livestock [58]. Ethiopia as part of African countries, these gaps are significantly seen and caused for the reduction and poor utilization of the livestock genetic resources. Hence, apart from supporting policy which is the major infrastructure in breed conservation and utilization program, infrastructures like physical facilities, functioning recording and genetic evaluation systems, efficient and workable organizational and institutional frameworks and linkages, well trained personnel and longterm financial support are critically thought and be in place. The strong links between these mentioned components are also essential [56, 55, and 54).

\subsection{Organizing of breeders association for arresting genetic erosion}

Cattle breeders association can be one alternative to arrest the erosion of the indigenous gene pool of the various cattle breeds. In line with this, [59] indicated some of the successful breeder societies that have helped to make use different economic important traits of the breeds. Examples of the breeders ${ }^{\text {ee }}$ societies are the Boran breed societies formulated in various countries like Kenya, Zambia and Australian [60]. The Boran cattle breed breeders ${ }^{\text {ee }}$ society in South Africa is also one of the strongest bovine breed society established in the beginning of 1960s [61]. For the success of utilizing, for instance, from economic benefits of Boran cattle breed, the breeders ${ }^{\text {ee }}$ societies had contributed a lot in outlining and designing the conservation and improvement programs. Therefore, Ethiopia can adopt a lot from those countries and show efforts for the implementation. [62] had also suggested the importance of formation of breeders ${ }^{\text {ee }}$ society in Ethiopia.

\subsection{Production system specific breed improvement program}

Ethiopia is characterized in having various production systems ranging from intensive livestock production system, though this very limited share and coverage compared to others, to pastoral based livestock production system. The diverse agro-ecologies the country is endowed with had contributed to have such numerous production systems that demand to understand the genetic diversity of the animal genetic resources accordingly. Therefore, the breed conservation and improvement programs should be carefully tailored to the specific production systems.

\subsection{System based reduction of cattle number in breed improvement program}

Apart from the genetic introgression of breed admixture, especially in countries like Ethiopia, the within population genetic diversity is incomparably higher than the between population genetic diversity. This is because of the fact that the practice of extensive random mating and absence of selection. This allows poorly performing individual animals to be reproduced. Therefore substantial reduction of number of animals should be part of the breeding program to be implemented. Such strategies will have simultaneous advantages in taking the edge of environmental degradation due overstocking, reduce environmentally harmful methane

Volume 6 Issue 12, December 2017 


\section{International Journal of Science and Research (IJSR) \\ ISSN (Online): 2319-7064}

Index Copernicus Value (2016): 79.57 | Impact Factor (2015): 6.391

emissions and helps to utilizes potential advantages of ecologically and environmentally friendly breeds [53].

\subsection{Applying informed conservation programs}

Conservation and breeding programs should also be supported with information technology. In this era of information technology one can dig maximum information from the genomic data of a given population that can provide to design efficient and accurate conservation and improvement programs. In line with this, [46] indicated that integration of the advanced information technology with the genomics and bio-informatics allows collection and realtime remittance of the biological data for safe storage and management. This in turn provides opportunities for fast turnover and feedback potentially to a wide variety of stakeholders. Not only genomic information together with advanced information technology facilitates conservation and utilization of the animal genetic resources but also the advancement of reproductive technology highly helps for the breed conservation and improvement program implementation [46].

\subsection{Introducing and scaling up of indigenous resource management practices}

Short term development interventions are one of the bottle necks in affecting the sustained survival of indigenous cattle populations in their own natural habitat. For instance, the traditional natural resource management practice of the Borana pastoralists has been severely disturbed mainly by such inappropriate development interventions [50]. In this area numerous water ponds in the traditional wet season pastures were constructed which eventually discouraged seasonal mobility of herds and opportunistic resource exploitation. Besides, the indigenous institutional and social networks by which pastoralists governed access to pasture and water resources have been severely compromised [50]. The replacement trend of large-framed Ethiopian Boran (Qorti) by small size type of Boran (Ayuna) can be a very good indicative. According to [50] large framed Boran cattle are considered not competitive when the grazing resources are scarce and the pastoralists' select small sized type of Boran cattle which have lower demands on forage. Side by side pastoralists are increasing the adoption of small ruminants and camels. One of the root causes of the species replacement is the development intervention introduced in the area that highly disturbed the indigenous and traditional practices accustomed by pastoralist in governing the natural pasture and water resources [53].

Since longtime ago, farmers especially pastoralists, used to have their own practices to manage and utilize the resources they have and had sustainably employed their practices and utilized the genetic resources. Therefore, new interventions should compromise the local context of indigenous practices which pastoralist or farmers have been acquainted with to meet the intended objectives in any of the development programs. This helps the pastoralists to efficiently utilize the resources they have and maintain their indigenous cattle breeds.

\subsection{Maintaining and uniting traditional social structures}

In the local community, there are ample of traditional social structures which had been, perhaps have been, functioning since long time before. Those social structures contribute in resolving conflicts in between, predicting the upcoming natural as well as human intervened disasters and other advantages. The traditional social structure of the Borana people which have maintained for long in managing the livestock production and productivity issues can be a very good example [50]. Next to Abba gadda (the president) Abba guya (delegate for water use and maintenance), Abba herrega (delegate for water management), Abba quaee (Convener of ad hoc meeting) and Aburro (Range scouter for the assessment of current range conditions) are facilitators who are supposed to manage livestock and livestock related resource management issues [41]. Therefore, appreciating the system, identifying the gaps in the system and contributing in the system by providing modern tools and inputs would be helpful for better conservation and utilization of the breeds.

The breeding strategies to be designed should also look into such indigenous practices within the community and one can easily and successfully demonstrate to farmers and implement activities like livestock recording, evaluation of data and supporting the farmers with selection tools. According to[56] most breeds have been developed based on traditional knowledge and improved through human interventions and natural selection. However, only structured and systematic breeding programs designed have resulted in the impressive genetic improvements starting in the 20th century [63].

\subsection{Revitalizing the closed ranches and formulating new ones}

Any one may have a look at the experience of other countries like Australia, South Africa and others, the key destinations for implementation of breed conservation and improvement programs are ranches, multiplication centers and farms. These farming areas have contributed a lot for their success of benefit from their cattle genetic resource. In Ethiopia, from the 1950 s to 1970 s there are indications that scholars and respective bodies exerted their efforts in establishing ranches, multiplications centers and farms. Some of them are Metekel Fogera cattle ranch, Wolaita cattle ranch, Jigjiga ogaden cattle ranch, Dida Tuyura Boran cattle and Abernossa Boran cattle ranch. Many thousands of animals from those ranches have been disappeared together with the ranches. This devastating action is a big treat in losing the diversity of indigenous livestock resources which was conserved for future use. Still there are indications to shift the remaining ranches, multiplication centers and farms. The only active ranches in this time are Dida Tuyura Boran cattle ranch at Borana, Metekel Fogera cattle ranch at Chagni, Begait cattle ranch (newly established) at Humera and Horro cattle ranch at Bako. These ranches would have contributed a lot if they were supported with soft as well as physical infrastructures and tools. Demolishing cannot be an alternative for success and better utilization of genetic resources rather unavertly failure. Keeping the existing

Volume 6 Issue 12, December 2017

www.ijsr.net

Licensed Under Creative Commons Attribution CC BY 


\section{International Journal of Science and Research (IJSR) ISSN (Online): 2319-7064}

Index Copernicus Value (2016): 79.57 | Impact Factor (2015): 6.391

ranches, reviving the lost ones is not a dead lock option rather there is still an opportunity to replace back.

\subsection{Use of genomic information as conservation and selection tools}

The advent of cheaper, faster sequencing technologies and the realization of good draft sequences and development of SNP chip technologies for livestock species have contributed to our understanding on many ways to further improve our important food species [64]. Genomic studies analyzing between and within breeds can be used as an effective and significant conservation tool in conservation programs as a basis for understanding geographical distribution of variation [65]. According to [1], genomic tools may assist the management of ex situ populations and reintroductions by providing increased precision and accuracy of estimates of neutral population genetic parameters and by identifying specific loci of importance, which is essential for selecting founder individuals. Moreover, it provides exciting opportunities to assess differential rates of introgression across different genomic regions following hybridization. These days, in developed countries the uses of genomic tools have heightened practical implications for designing breeding programmes. It has the potential to radically alter the structure of livestock breeding programmes [66]. Therefore, integration of genomic conservation and selection tools is indispensible to hasten in conservation and breed improvement of indigenous livestock genetic resources in Ethiopia.

\subsection{Developing in-situ and ex-situ breed conservation and improvement programs}

Indigenous cattle populations are declining and there is lack of breeding bulls and high genetic admixture in village herds. This calls for maintenance of breed based nucleus populations (ex-situ) as a source of pure genetic material to maintain and buildup purity of village herds and community based breeding programs (in-situ). Nucleus breeding programs entail a continuous supply of replacement bulls to villages, usually at no cost or highly subsidized prices. Yet community-based conservation may be uncertain, especially for highly threatened breeds, and thus complementary nucleus-village based programs are suggested. Thus a breed based breeding scheme that integrates the merits of stationbased nucleus herd and village (community-based) breeding scheme should be designed and implemented.

\subsection{Creating sustainable institutional frame work}

Well coordinated institutions and organizations constitute important parts and roles for the development of the livestock sector [67], [63]. For better utilization and conservation of these indigenous cattle genetic resources, a well coordinated institutional arrangement is a key issue. Apart from the between institutional readability, the arrangement should include dissemination of information and networking at different levels. To implement this concerned regional, national and international institutions should take up the lead responsibility.

\subsection{Demand based dissemination of cattle genetic} resources and development interventions

In Ethiopia, attempts have been made to improve indigenous cattle breeds mostly either by crossbreeding with exotic breeds or with themselves. However, in majority of the cases attempts have failed due to mainly indiscriminate dissemination of breeds to areas where the breed is not geographically and socio-culturally supported usually leading to wrong breeding objectives and neglect of the potentials of various indigenous breeds of livestock. Therefore, approaches better adapted to the potential of indigenous livestock breeds must be developed. In this regard, [67] suggested that realistic ways of improving these genetic resources must be chosen and applied in the context of environmental constraints and socio-economic demands and within the resources available. In a nut shell, for sustainable maintenance of indigenous cattle genetic resources, suitability mapping of physical and socio-cultural environments should be done before dissemination of any potential breeds.

\subsection{Widen utilization of reproductive technology tools}

Since in last few years, there is an effort in utilization of synchronization for bringing them into estrus cycle to support AI performance in indigenous cows. Despite the limitation in using, for instance, the Boran or exotic semen for Sheko cows, this technique is helpful to bring the threatened indigenous breeds back. However, it seems imperative to mention about consequences of the former approach in particular that needs due care so that the intervention would not embark back after sometime.

\section{Conclusion}

Agro-ecological zones, directly influenced by climate variation are perhaps more diverse on the Ethiopia than on any other countries of African continent. Consequently Ethiopian indigenous cattle inhabiting these areas are expected to show a variety of environmental adaptation key to their survival in local production systems. The genetic diversity of Ethiopian indigenous cattle represent a unique resource and opportunity for tackling the challenges of livestock productivity faced by the country, including the increasing demand for livestock products and the consequence of climate instability and changes. It is up to us to understand it and to exploit it now for the benefit of the nation and its people. The information about the past and current situation of indigenous cattle of Ethiopia showed that the situation of these breeds is very critical. Therefore, there is a need to devise strategies to conserve and improve these cattle breeds based on the challenges that threatens. Use of new biological and information technologies is imperative to facilitate the genetic restoration process. Various ongoing development interventions like Artificial Insemination and introduction of genotypes into new environments that are exacerbating threat of the breeds should be totally avoided by revising and designing sound approaches for cattle Conservation and improvement programs. Strict regulations and bylaw should also be in place for illegal movement of breeding cattle to the neighboring countries. Our live animal export practice (legal) is also the most important point that 


\section{International Journal of Science and Research (IJSR) \\ ISSN (Online): 2319-7064}

Index Copernicus Value (2016): 79.57 | Impact Factor (2015): 6.391

needs to be seen critically. Live animals are exported without castrating them. No one seems aware about transporting the gene pool to outside in contrary to the strict genetic resource transfer regulation we have.

\section{Acknowledgments}

I thank Dr. Gebremedhin and Mr. Gebrehaweria Kidane for their constructive suggestions and helpful comments on the preparation of the manuscript.

\section{References}

[1] Buffum B. C. (1909). Arid Agriculture: A Hand-book for the Western Farmer and Stockman. Self published, Worland, WY, USA.

[2] Otten, D. and H. F. Van den Weghe. (2011). The Sustainability of Intensive Livestock Areas (ILAS): Network system and conflict potential from the perspective of animal farmers. Int. J. Food Syst. Dyn. 2:36-51.

[3] Houghton, J. T. and Callander B. A. (1992). Climate change 1992: the supplementary report to the IPCC scientific assessment. Cambridge University Press, Cambridge, UK. Hu, Z.-L., C. A. Park, X.-L. Wu, and J. M. Reecy. 2013. Animal QTLdb: an improved database tool for livestock animal QTL/association data dissemination in the post-genome era. Nucl. Acids Res. 41:871-879.

[4] Nardone, A., B. Ronchi, N. Lacetera, M. S. Ranieri, and U. Bernabucci. (2010). Effects of climate changes on animal production and sustainability of livestock systems. Livest. Sci. 130:57-69.

[5] Renaudeau, D., A. Collin, S. Yahav, V. De Basilio, J. L. Gourdine, and R. J. Collier. (2012). Adaptation to hot climate and strategies to alleviate heat stress in livestock production. Animal 6:707728.

[6] Rege JEO (1999). The state of African cattle genetic resources. I. Classification framework and identification of threatened and extinct breeds. Anim. Genet. Resour. Inform. Bull. No. 25: 1-25.

[7] Hanotte O, Tawah CL, Bradley DG, Okomo M, Verjee Y, Ochieng J et al (2000). Geographic distribution and frequency of a taurine Bos taurine and an indicine Bos indicus Y specific allele amongst sub-Saharan African cattle breeds. Mol Ecol 9: 387-396.

[8] Hanotte O Bradley DG Ochieng JW Verjee Y Hill EW Rege JEO (2002). African pastoralism: genetic imprints of origins and migrations. Science 296: 336-339.

[9] Epstein H (1971). The origin of the domestic animals of Africa. African Publishing Corporation (APC). Volume I. 101 Fifth Avenue, New York, N.Y. 10003, U.S.A.

[10] Ayalew W, Getahun E, Tibbo M, Mamo Y and Rege JEO (2003). Current State of Knowledge on Characterization of Farm Animal Genetic Resources in Ethiopia. Proc.11th Annual conf. Ethiopian Soc. Anim. Prod. pp. 1-22.

[11] IBC (Institute of Biodiversity Conservation). (2014). Ethiopia's Fifth National Report to the Convention on Biological Diversity.

[12] Takele TD, Workneh A and Hegde BP (2011). Breed and trait preferences of Sheko cattle keepers in southwestern

Health Prod (2011) 43:851-856.

[13] IBCR (2001). Institute of Biodiversity Conservation and Research. IBCR, Addis Ababa, Ethiopia. Available at: http://www.telecom.net.et/ ibcr/.

[14] Rege JEO, Kahi AK, Okomo-Adhiambo M, Mwacharo J and Hanotte O (2001). Zebu cattle of Kenya: Uses, performance, farmer preferences, measures of genetic diversity and options for improved use. ILRI (International Livestock Research Institute), Nairobi, Kenya. 103 P.

[15]Zewdu W, (2004). Indigenous cattle genetic resources, their husbandry practices and breeding objectives in North-western Ethiopia. An MSc Thesis Submitted to School of Graduate Studies, Alemaya University.

[16] Nigatu A, Getachew G and Workneh A (2002). Genetic dilution of the Ethiopian Boran cattle. pp 377-381. In: Proceeding of 10th National Conference. Ethiopian Society Animal Production (ESAP). Aug 21-23, 2002. Addis Ababa, Ethiopia.

[17]Zewdu W, (2010). Genetic Differentiation and Metabolic Adaptation of Cattle Populations along the Slopes of Simien Mountains of North Western Ethiopia. Doctoral Thesis: University of Natural Resources and Applied Life Sciences, Department of Sustainable Agricultural Systems Division of Livestock Sciences. Vienna, Austria November 2010.

[18] Pilling D (2010). Threats to animal genetic resources for food and agriculture: approaches to recording, description, classification and analysis. Food and Agriculture Organization of the United Nations. Animal Genetic Resources, 2010, 47: 11-22.

[19] Reist-Marti SB, Simianer H, Gibson J, Hanotte O, Rege JEO (2003). Weizman ${ }^{e e}$ s approach and conservation of breed diversity: an application to African cattle breeds. Conserv. Biol., 17: 1299-1311.

[20]Zewdu E, Hailu D, Kim SW, Tadelle D, Kim KS (2012). Comparison of SNP Variation and Distribution in Indigenous Ethiopian and Korean Cattle (Hanwoo) Populations. Genomics Inform 2012; 10(3): 200-205.

[21] Murray, M., J. C. M. Trail, C. E. Davis, and S. J. Black. (1984). Genetic resistance to African trypanosomiasis. J. Infect. Dis. 149:311-319.

[22] Mattioli, R. C., V. S. Pandey, M. Murray, and J. L. Fitzpatrick. (2000). Immunogenetic influences on tick resistance in African cattle with particular reference to trypanotolerant N'Dama (Bos taurus) and trypanosusceptible Gobra zebu (Bos indicus) cattle. Acta Trop. 75:263-277.

[23] Murray, G. G. R., M. E. J. Woolhouse, M. Tapio, M. N. MboleKariuki, T. S. Sonstegard, S. M. Thumbi, A. E. Jennings, I. C. van Wyk, M. Chase-Topping, and Kiara H. (2013). Genetic susceptibility to infectious disease in East African Shorthorn Zebu: A genome-wide analysis of the effect of heterozygosity and exotic introgression. BMC Evol. Biol. 13:246.

[24] Njogu, A., R. Dolan, A. Wilson, and P. Sayer. (1985). Trypanotolerance in East African Orma Boran cattle. Vet. Rec. 117:632-636.

[25] Rege, J. E. O. and C. L. Tawah. (1999). The state of African cattle genetic resources II. Geographical distribution, characteristics and uses of present-day breeds and strains. Anim. Genet. Res. Inf. 26:1-25. 


\section{International Journal of Science and Research (IJSR) \\ ISSN (Online): 2319-7064}

Index Copernicus Value (2016): 79.57 | Impact Factor (2015): 6.391

[26] Okello, S. and E. N. Sabiiti. (2006). Milk production of indigenous Ankole cattle in Uganda as influenced by seasonal variations in temperature, rainfall and feed quality. Makerere Univ. Res. J. 1:73-92.

[27]Zerabruk M, Vangen O and Haile M (2007b). The status of cattle genetic resources in North Ethiopia: On-farm characterization of six major cattle breeds. Animal Genetic Resources Information, No. 40, 2007.

[28]Zerabruk M, Bennewitz J, Kantanen J, Olsaker I, Vangen O (2007a). Analysis of genetic diversity and conservation priorities for six north Ethiopian cattle breeds. J. Anim. Breed. Genet. 124: 236-41.

[29]Zerabruk M and Vangen $O$ (2005). The Abergelle and Irob cattle breeds of North Ethiopia: description and onfarm characterization. Anim. Genet. Resource Inform 36: 7-20.

[30] ILRI (International Livestock Research Institute) (2007).. The ,big five ee African vintage cows. Available at: http://www.ilri.org/ilrinews/index.php/archives/546.

[31] Tatek W and Abegaz B (2013). Current Status and Future Prospects of the Endangered Sheko Breed of Cattle (African Bos Taurus) in Ethiopia: A Review Paper. Global J.Sc.Frontier Research Agriculture and Veterinary. Volume 13 Issue 13 Version 1.0.

[32] Takele TD, Workneh A and Hegde BP (2012). Farmerse perceptions on trypanosomosis and trypanotolerance character of the taurine Sheko. Trop Anim Health Prod (2012) 44: 609-616.

[33] Takele T, Workneh A and Hegde BP (2007). On-farm characterization of Sheko breed of cattle in southwestern Ethiopia. Ethiopian Journal of Animal Production 7(1): 89-105.

[34] Dadi H, Mwacharo J, Tibbo M, Takahashi Y, Nomura K, Hanada H and Amano T (2009). No evidence for a recent genetic bottleneck in the endangered Sheko cattle breed (African Bos taurus) revealed by microsatellite analysis. Available from Nature preceding http://hdl.handle.net/10101/npre.2009.3925.

[35] Dadi H, Tibbo M, Takahashi Y, Nomura K, Hanada H and Amano T (2008). Microsatellite analysis reveals high genetic diversity but low genetic structure in Ethiopian indigenous cattle populations. International Society for Animal Genetics, Animal Genetics, 39: 425-431

[36] Hanotte, O., T. Dessie, and S. Kemp. (2010). Time to tap Africa's livestock genomes. Science (Washington) 328:1640-1641.

[37] Rege E, Lemecha H, Mulatu W, Hussein I, , Tekle T, Abdicho S and Ayalew W (2006). Response of four indigenous cattle breeds to natural tsetse and trypanosomosis challenge in the Ghibe valley of Ethiopia. Vet. Parasitol. 141, 165-176.

[38]DAGRIS (2007). The Domestic Animal Genetic Resources System. In http://dagris.ilri.cgiar.org/distlist.asp? $\mathrm{SC}=1 \& \mathrm{GC}=\& \mathrm{BN}$ $=\& \mathrm{RC}=\& \mathrm{SRC}=\& \mathrm{CC}=70$.

[39] Hoda A, Sena L and Hykaj G (2012). Genetic diversity revealed by AFLP markers in Albanian goat breeds. Archives of Biological Sciences 64 (2): 799-807.

[40]Lemecha, H., W. Mulatu, I. Hussein, E. Rege, T. Tekle, S. Abdicho and W. Ayalew. (2006). Response of four indigenous cattle breeds to natural tsetse and trypanosomosis challenge in the Ghibe valley of Ethiopia. Vet. Parasitol. 141:165-176.

[41] Kugonza, D. R., M. Nabasirye, D. Mpairwe, O. Hanotte, and A. Okeyo. (2011). Productivity and morphology of Ankole cattle in three livestock production systems in Uganda. Anim. Genet. Res. 48:13-22.

[42] Pullan, N. B. and R. J. Grindle. (1980). Productivity of white Fulani cattle on the Jos plateau, Nigeria. IV. Economic factors. Trop. Anim. Health Prod. 12:161170.

[43] Gebremedhin, B., D. Hoekstra, and S. Jemaneh. (2007). Heading towards commercialization? The case of live animal marketing in Ethiopia. International Livestock Research Institute, Nairobi, Kenya. Glazier, A. M., J. H. Nadeau, and T. J. Aitman. 2002. Finding genes that underlie complex traits. Science 298:2345-2349.

[44] De Roos, A. P. W., B. J. Hayes, R. J. Spelman, and M. E. Goddard. (2008). Linkage disequilibrium and persistence of phase in Holstein-Friesian, Jersey and Angus cattle. Genetics 179:1503-1512.

[45] Okeyo. A, Persley, G. and Kemp, S. (2010). Livestock and Biodiversity: The Case of Cattle in Africa. Paper prepared for presentation at the "Biodiversity And World Food Security: Nourishing The Planet And Its People" conference conducted by the Crawford Fund for International Agricultural Research, Parliament House, Canberra, Australia, 30 August - 1 September, 2010.

[46] Getachew, G. and Nigatu A (2001). A snap Survey on Pastoralists perception on genetic dissipation of Boran Cattle. Unpublished Report.

[47] Terefe, E., A. Haile, W. Mulatu, T. Dessie, and O. Mwai. (2015). Phenotypic characteristics and trypanosome prevalence of Mursi cattle breed in the Bodi and Mursi districts of South Omo Zone, southwest Ethiopia. Trop. Anim. Health Prod. 47:485-493.

[48] Sisay G (1996). Characterization of some indigenous cattle breeds of Ethiopia using blood protein polymorphisms. M.Sc. Thesis. Alemaya University of Agriculture, Ehtiopia.

[49] Fedlu H, Endashaw B, Workneh A and Tadelle D (2007). Genetic variability of five indigenous Ethiopian cattle breeds using RAPD markers. African Journal of Biotechnology, $6 \quad$ (19): 2274-2279, http://www.academicjournals.org/AJB

[50] Sabine H, Barbara R, Jörg S and Workneh A (2004). Disturbed Traditional Resource Management affects the Preservation of the Boran Cattle in their Original Habitat. Eth. J. Anim. Prod. 4(1): 33-44

[51] Nigatu A, (2001). Is the Ethiopian Boran under threat? Survey conducted from 15-20 Sep. A Report Submitted to ILRI/AnGR. International Livestock Research Institute, Addis Ababa, Ethiopia.

[52] Diress TA, Mitiku H, Fikru Y and Lulseged T (2003). Assessment of rangeland condition and livestock mobility pattern in Aba ${ }^{e}$ ala wereda, North Afar: field survey and application of geographic information systems (GIS). In: Allsopp, A.R. et al. (Eds), Proceedings of the 7th International Rangeland Congress, 26 July-1 August 2003, Durban, South Africa.

\section{Volume 6 Issue 12, December 2017}




\section{International Journal of Science and Research (IJSR) \\ ISSN (Online): 2319-7064}

Index Copernicus Value (2016): 79.57 | Impact Factor (2015): 6.391

[53] Mekuriaw, G. and Kebede, A. (2015). A review on indigenous cattle genetic resources in Ethiopia: adaptation, status and survival. Online J. Anim. Feed Res., 5(5): 125-137.

[54]FAO (2011). Food and Agriculture Organization of the United Nations. Developing the institutional framework for the management of animal genetic resources. FAO Animal Production and Health Guidelines. No. 6. Rome.

[55]FAO (2010). Food and Agriculture Organization of the United Nations. Breeding strategies for sustainable management of animal genetic resources. In FAO Animal Production and Health Guidelines. No. 3. Rome.

[56]FAO (2009b). Food and Agriculture Organization of the United Nations. Livestock keepers - guardians of biodiversity. Rome.

[57]FAO (2009a). Food and Agriculture Organization of the United Nations. Threats to Animal Genetic ResourcesTheir Relevance, Importance and Opportunities to Decrease Their Impact. CGRFA Background Study Paper 50, pp. 55.

[58]FAO (2007). Food and Agriculture Organization of the United Nations. The State of the World 'e s Animal Genetic Resources for Food and Agriculture, edited by Barbara Rischkowsky and Dafydd Pilling. Rome, Italy.

[59] Strydom PE (2008). Do indigenous Southern African cattle breeds have the right genetics for commercial production of quality meat? Meat Science 80 (2008): 86-93.

[60]Mpofu N (2002). The multiplication of Africa ${ }^{\text {ee }}$ indigenous cattle breeds internationally: The story of the Tuli and Boran breeds. AGTR Case Study. Nairobi, Kenya:ILRI. https://cgspace.cgiar.org/handle/10568/3600.

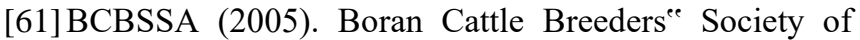
South Africa. The Boran breed manual in South Africa.

[62] Kefena E, Tadelle D, Zelalem Y and Aynalem H (2009). Cattle breeding strategies for sustainable genetic improvement in Ethiopia. Ethiopian Society of Animal Production (ESAP) 2009. Proceedings of the 17th Annual conference of the Ethiopian Society of Animal Production (ESAP) held in Addis Ababa, Ethiopia, September 24 to 26, 2009. ESAP, Addis Ababa 300 pp

[63]Zonabend E, Okeyo AM, Ojango JMK, Hoffmann I, Moyo S and Philipsson J (2013). Infrastructure for sustainable use of animal genetic resources in Southern and Eastern Africa. Animal Genetic Resources, Food and Agriculture Organization of the United Nations, 2013, 53: 79-93.

[64] Rothschild M and Graham SP (2014). Applications of genomics to improve livestock in the developing world. Elsevier Journal of Livestock Science, 166(2014):76-83 Available at: www.elsevier.com/locate/livsci

[65]Ryder OA (2005). Conservation genomics: applying whole genome studies to species conservation efforts. Cytogenet Genome Res, 108: 6-15.

[66] Goddard ME and Hayes BJ (2007). Genomic selection. J. Anim. Breed. Genet., 124: 323-330.

[67] Philipsson J, Rege JEO, Zonabend E and Okeyo A.M (2011). Sustainable breeding programmes for tropical farming systems In: Animal Genetics Training Resource, version 3, 2011.

\section{Author Profile}

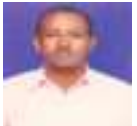

Berhane Hagos has received his BSc. Degree in Animal Production and Health from Haramaya University in 2006 and his MSc. Degree In animal Genetics and Breeding from Bahir Dar University in 2012 and now he is searching for his PhD Scholarship. 